\title{
Mass Spectrometric Profiling of N-Linked Oligosaccharides and Uncommon Glycoform in Mouse Serum with Head and Neck Tumor
}

\author{
Erika Lattová, ${ }^{\mathrm{a}, \mathrm{b}}$ Sonal Varma, ${ }^{\mathrm{c}}$ Tedros Bezabeh, ${ }^{\mathrm{c}}$ Ladislav Petruš, ${ }^{\mathrm{b}}$ and \\ Hélène Perreault ${ }^{\mathrm{a}}$ \\ ${ }^{a}$ Chemistry Department, University of Manitoba, Winnipeg, Manitoba, Canada \\ b The Institute of Chemistry, Slovak Academy of Sciences, Bratislava, Slovakia \\ ${ }^{\mathrm{c}}$ NRC Institute for Biodiagnostics, Winnipeg, Manitoba, Canada
}

\begin{abstract}
N-linked oligosaccharides obtained from total serum of mice with implanted head and neck tumors were analyzed and compared with those from control samples of healthy mice. Methods used include a combination of a derivatization procedure with phenylhydrazine (PHN) and analysis by matrix-assisted laser desorption/ionization mass spectrometry (MALDI-MS). Oligosaccharides were enzymatically released from total serum with PNGaseF and purified by high-performance liquid chromatography (HPLC) on a reversed-phase column. Mass spectra contained ion peaks of labeled oligosaccharides and MS/MS experiments provided useful data for the structural elucidation of these compounds. More than 40 $\mathrm{N}$-glycans with compositions characteristic of high-mannose, hybrid, complex, neutral, and sialylated structures were identified in the serum of tumoral mice. Significant differences between samples were observed with respect to the abundances of high mannose and hybrid glycans. These oligosaccharides showed higher relative intensities in the spectra obtained from the cancer sera. Complex sialylated oligosaccharides had similar abundances in both types of sera, with the exception of fucosylated biantennary disialylated oligosaccharide, which was mostly detected with lower abundance in control samples. In the MALDI spectra, several minor species corresponded to uncommon carbohydrates. These structures have been investigated in detail by MS/MS. Among these novel glycoforms, a few sialylated oligosaccharides without a free reducing end were identified. Also, glycans with an extra $60 \mathrm{u}$ were observed and likely feature the presence of a 2-acetamido-2-deoxyoctose residue attached on antennae of 3- or 6-linked mannose. (J Am Soc Mass Spectrom 2008, 19, 671-685) (C) 2008 American Society for Mass Spectrometry
\end{abstract}

$\mathrm{T}$ The importance of protein glycosylation as one mode of post-translational modification is reflected by the large number of glycosylated proteins employed by organisms in a myriad of biological processes [1]. It has been recognized that altered glycosylation is an universal feature of living cells and several studies have demonstrated that the changes in cellular glycosylation profiles can be also related to aggressive cancer cell behavior, such as tumor cell invasion and metastasis [2-8]. As cancer cells can produce oligosaccharides that are significantly different from those in normal cells, comparative studies between glycoprotein carbohydrates produced by malignant cells and normal cells may provide useful information for diagnosis, prognosis, and immunotherapy of tumors [9].

Mass spectrometry (MS) has been used extensively as the most sensitive method for the analysis of carbo-

Address reprint requests to Dr. Erika Lattová or Prof. Hélène Perreault, Chemistry Department, University of Manitoba, 144 Dysart Road, Winnipeg, MB R3T 2N2, Canada. E-mail: lattovae@cc.umanitoba.ca perreau@ cc.umanitoba.ca hydrate molecules [10-14]. Moreover, modern MS instruments allow the measurement of unseparated mixtures, and make possible the identification of trace amounts of glycans in biological materials [15]. Nonetheless, biochemical analysis of carbohydrates is generally complicated, not only because of their lower concentration relative to with proteins, but also because of the structural diversity of molecules, anomericity, linkage positions, and branching patterns of monosaccharides. Moreover, carboxylic groups cause sialylated oligosaccharides to ionize with less efficiency than neutral oligosaccharides, making MS analysis of glycans more difficult in the positive ion mode [16]. Neutral oligosaccharides can be separated from acidic ones by various techniques before analysis $[17,18]$, or to chemically modify the carboxyl group by methods such as methyl esterification [19], permethylation [20], or amidation [21].

Recently, mass spectrometric approaches have become popular for the screening of oligosaccharide profiles in blood from assorted sources. Several studies have demonstrated changes in the glycosylation profiles of glycoproteins in sera associated with a variety of 

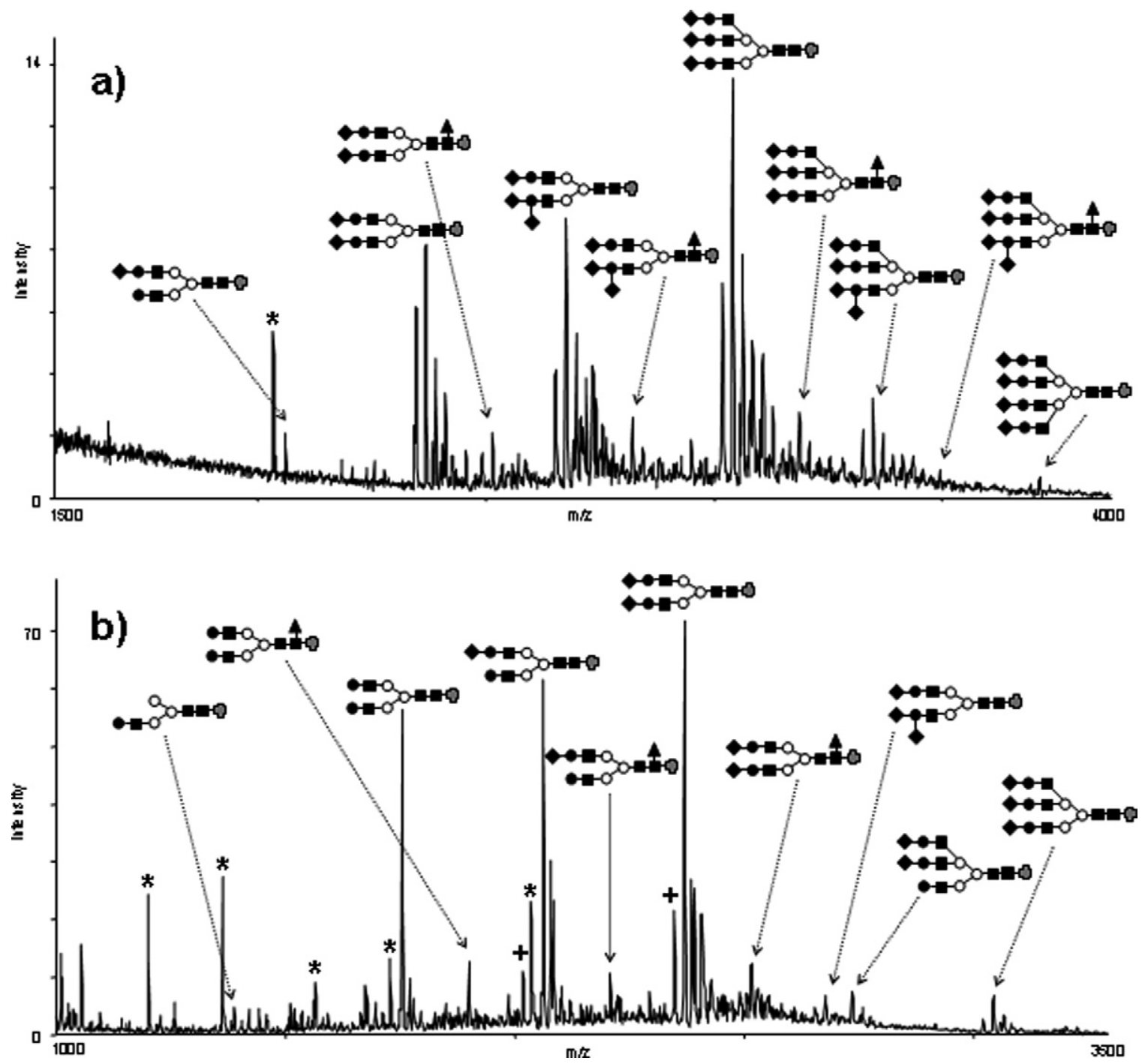

Figure 1. Representative positive MALDI-QqTOF mass spectra recorded from HPLC fractions of total mouse serum. Samples were first digested with trypsin/chymotrypsin. Oligosaccharides were released with PNGaseF and labeled with PHN: (a) Fraction 1 from healthy serum; (b) Fraction 2 from healthy serum; (c) Fraction 2 from tumor serum; (d) Fraction 3 obtained from tumor serum. For details see Tables 1 and 2. Symbols: (filled triangle) Fuc; (filled circle) Gal; (open circle) Man; (filled square) GlcNAc; (filled diamond) NeuGc; *oligosaccharides with dehydrated monosaccharide residue; +oligosaccharides with a $60 \mathrm{u}$ mass increment.

diseases. Among them, serum obtained from woodchucks diagnosed with hepatocellular carcinoma had higher levels of oligosaccharides with core $\alpha$-1,6-linked fucose [22]. Serum of patients with cirrhosis showed a heterogeneous distribution of $\mathrm{N}$-glycans compared with healthy samples [23]. In a study on human pancreatic cancer, serum samples contained $\mathrm{N}$-glycans with increased fucosylation and sialylation relative to those from healthy individuals [24]. Samples in the study of ovarian cancer patients also showed a number of neutral oligosaccharides that appeared related to cancer [25]. Despite intense research efforts, many times the findings are relevant only to the particular biological material on which the analysis was performed. Each approach for preparing samples has some advantages and disadvantages, especially regarding the analysis of tissue or blood. Consequently for most diseases, including cancer ailments, the facts and links still need to be thoroughly understood and validated by obtaining as much information as possible to replicate the findings.

The original aim of this study was to analyze oligosaccharides enzymatically released from total serum of nude mice with implanted head and neck tumors. The term "head and neck cancer" generally refers to malignant growths that arise from the surface epithelium of the upper aerodigestive tract. About 50,000 cases of head and neck cancers are diagnosed in the USA and Canada every year with $\sim 25 \%$ of these patients eventually dying from this disease [26]. Squamous cell carcinomas (SCC) are the most common malignant 

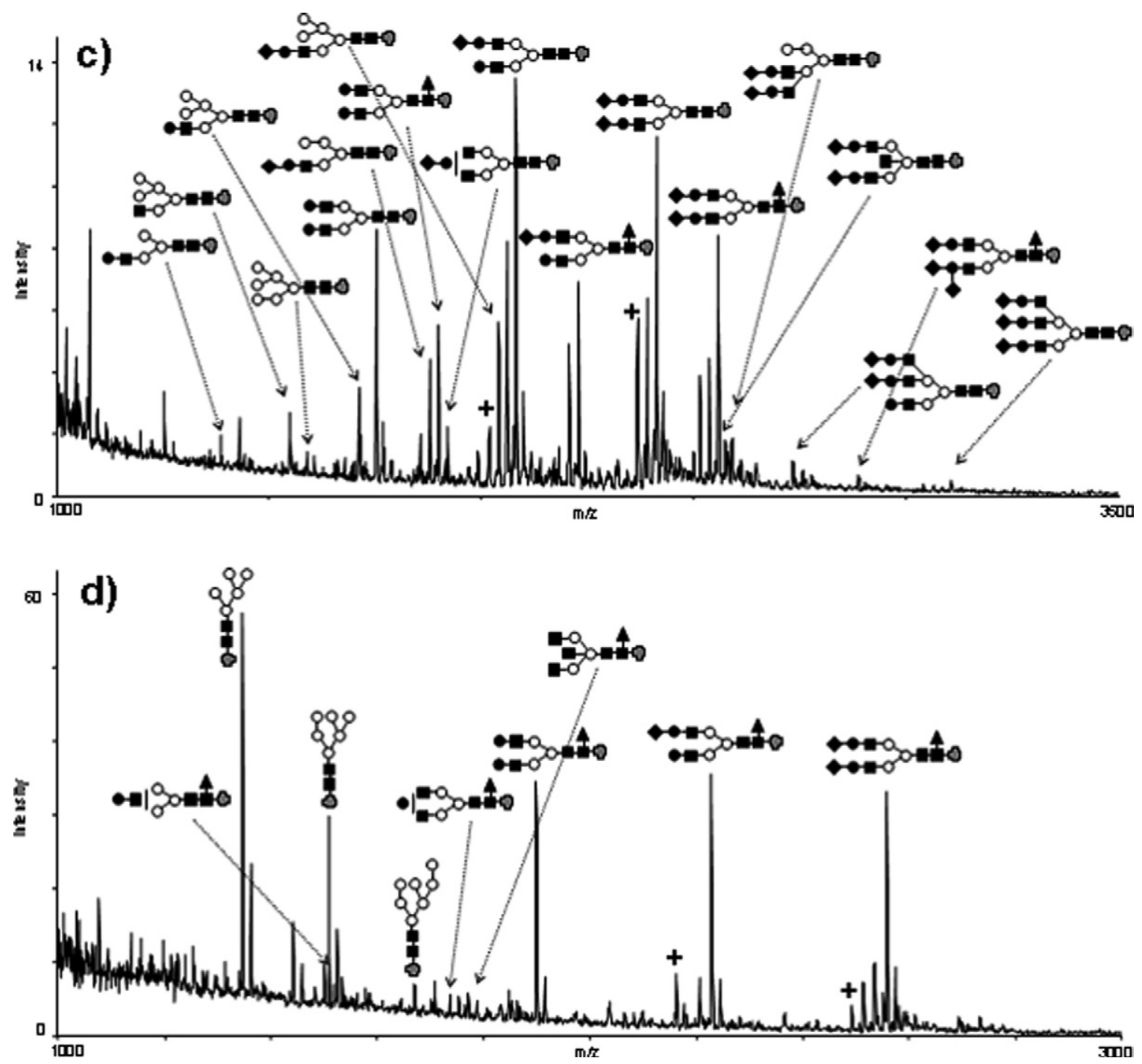

Figure 1. Continued

histology in the head and neck region. SCC of the upper aerodigestive tract is one of the leading causes of death worldwide. Previously it was demonstrated that the sera of patients with head and neck carcinomas show tumor-size-dependent elevations of serum gangliosides [27]. In view of the role of glycosylation inhibitors, it was postulated that chemical manipulation of glycosylation can be a useful therapeutic strategy for successful chemotherapy against head and neck cancer [28].

In our previous recent articles we introduced development phenylhydrazine (PHN) derivatization for labeling oligosaccharides from commercial sources [29, 32]. The present study for the first time demonstrates application of this method for mass spectrometric analyses of carbohydrates from real complex biological material. Oligosaccharides obtained from the serum of cancerous mice were tagged with PHN and compared also with profiles of oligosaccharides from control sera.
For purification of samples, reversed-phase high-performance liquid chromatography (RP-HPLC) was employed and all glycans were analyzed by matrix-assisted laser desorption ionization (MALDI) mass spectrometry. Acidic N-glycans were characterized in one step together with neutral oligosaccharides, without additional procedures to eliminate sialylated residues. Particular attention was paid to some oligosaccharide of uncommon composition, described for the first time in this study. Structures for these forms are suggested according to highly reproducible tandem MS (MS/MS) data.

\section{Experimental}

\section{Materials and Reagents}

Serum samples for this project were obtained from eight CD-1 nude mice, which were injected with human head and neck cancer cells (FaDu cell line) in the right flank. 
Table 1. Structures of derivatized N-glycans with masses $>1000$ Da recorded from mice serum on the MALDI-QqTOF mass spectrometer in positive mode. Stars refer to ion abundances

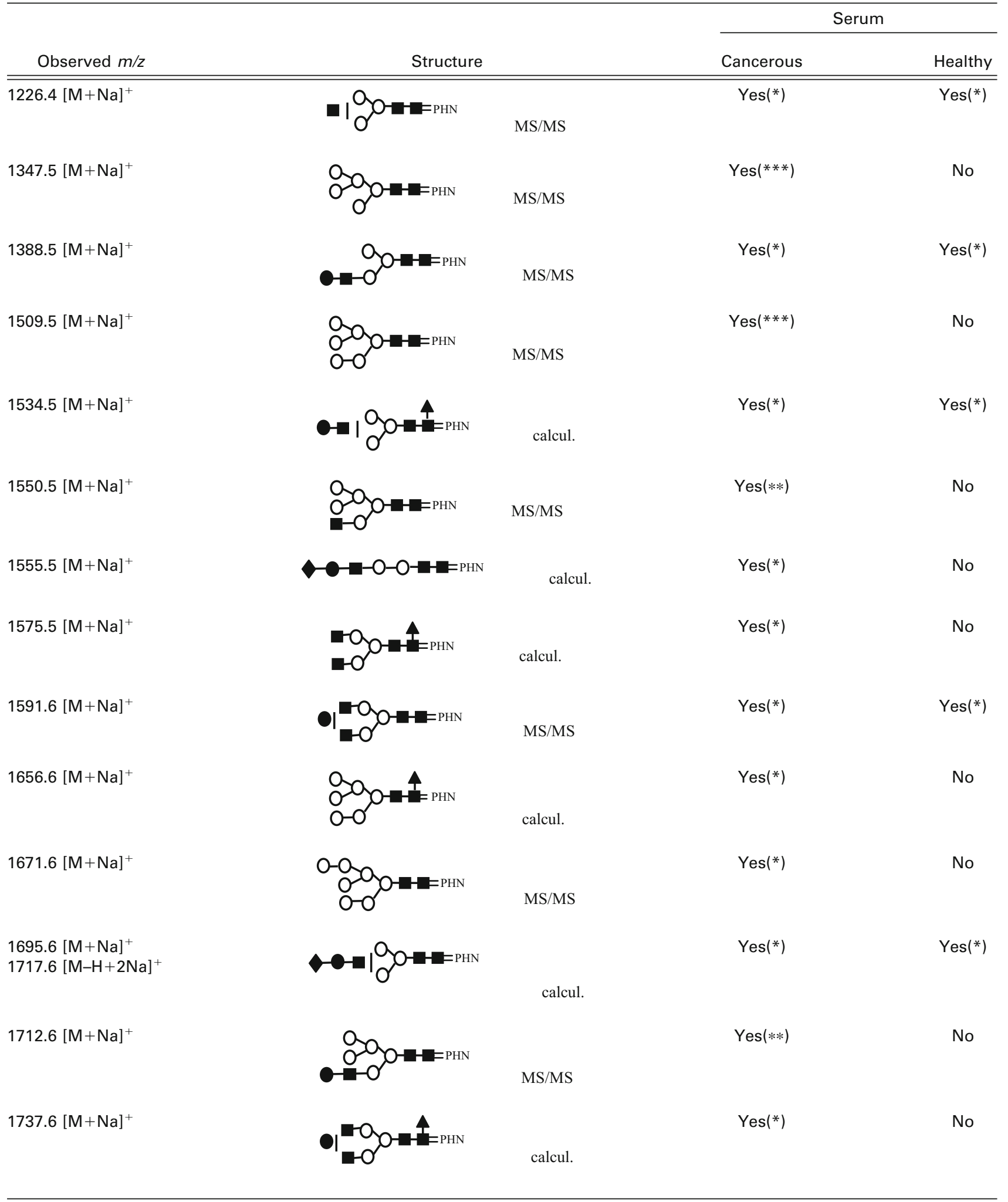


Table 1. Continued

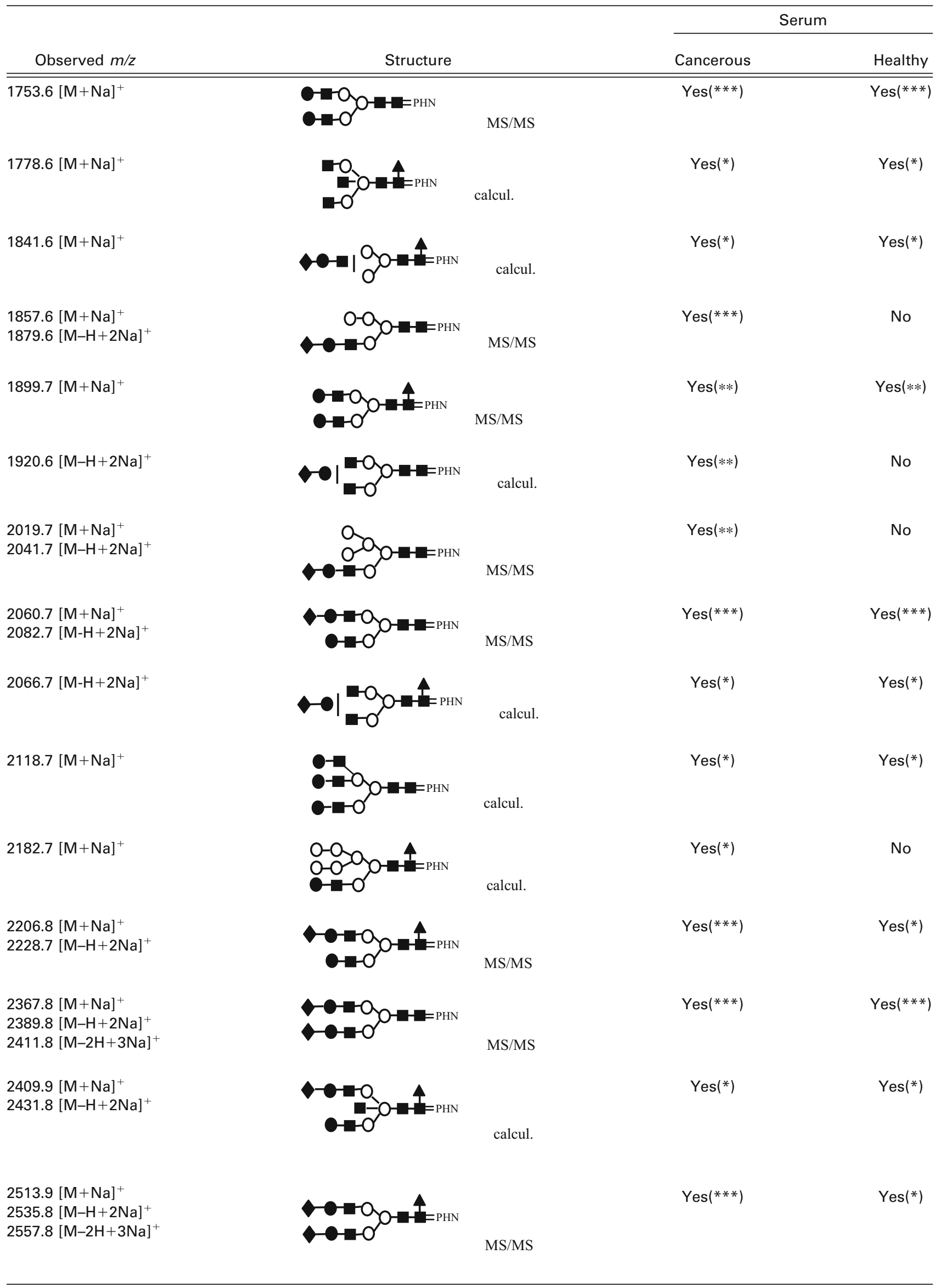


Table 1. Continued

\begin{tabular}{|c|c|c|c|}
\hline \multirow[b]{2}{*}{ Observed $\mathrm{m} / \mathrm{z}$} & \multirow[b]{2}{*}{ Structure } & \multicolumn{2}{|c|}{ Serum } \\
\hline & & Cancerous & Healthy \\
\hline $2571.0[\mathrm{M}+\mathrm{Na}]^{+}$ & & $\operatorname{Yes}(*)$ & $\operatorname{Yes}(*)$ \\
\hline \multirow[t]{2}{*}{$2573.8[\mathrm{M}-2 \mathrm{H}+3 \mathrm{Na}]^{+}$} & & Yes $(*)$ & No \\
\hline & & & \\
\hline \multirow[t]{2}{*}{$\begin{array}{l}2674.7[\mathrm{M}+\mathrm{Na}]^{+} \\
2696.7[\mathrm{M}-\mathrm{H}+2 \mathrm{Na}]^{+}\end{array}$} & & Yes $(* * *)$ & Yes $(* * *)$ \\
\hline & & & \\
\hline $2716.9[\mathrm{M}+\mathrm{Na}]^{+}$ & & Yes $(*)$ & Yes $(*)$ \\
\hline $2732.8[\mathrm{M}+\mathrm{Na}]^{+}$ & & Yes $(* *)$ & Yes $(* *)$ \\
\hline $\begin{array}{l}2821.0[\mathrm{M}+\mathrm{Na}]^{+} \\
2886.9[\mathrm{M}-3 \mathrm{H}+4 \mathrm{Na}]^{+}\end{array}$ & & Yes $(* *)$ & Yes $(* *)$ \\
\hline \multirow[t]{2}{*}{$\begin{array}{l}3039.8[\mathrm{M}+\mathrm{Na}]^{+} \\
3061.9[\mathrm{M}-\mathrm{H}+2 \mathrm{Na}]^{+} \\
3105.9[\mathrm{M}-3 \mathrm{H}+4 \mathrm{Na}]^{+}\end{array}$} & & $\operatorname{Yes}(* * *)$ & Yes $(* * *)$ \\
\hline & & & \\
\hline \multirow[t]{2}{*}{$3185.9[\mathrm{M}+\mathrm{Na}]^{+}$} & & Yes $(* *)$ & Yes $(* *)$ \\
\hline & & & \\
\hline \multirow[t]{2}{*}{$3347.1[\mathrm{M}+\mathrm{Na}]^{+}$} & & Yes $(* *)$ & Yes $(* *)$ \\
\hline & & & \\
\hline \multirow[t]{2}{*}{$3493.2[\mathrm{M}+\mathrm{Na}]^{+}$} & & Yes $(*)$ & Yes $(*)$ \\
\hline & & & \\
\hline \multirow[t]{2}{*}{$3712.3[\mathrm{M}+\mathrm{Na}]^{+}$} & & $\operatorname{Yes}(*)$ & Yes $(*)$ \\
\hline & & & \\
\hline
\end{tabular}

Key symbols: GIcNAc; $\bullet \mathrm{Gal} ; \bigcirc \mathrm{Man} ; \boldsymbol{\Delta}$ Fuc; $\bullet \mathrm{NeuGc}$; ***abundant,

*minor. 
Blood was taken after 3 to 4 weeks when tumors reached a size between 6 and $10 \mathrm{~mm}$ in longest diameter. Control sera were obtained from five healthy mice of the same type.

Phenylhydrazine (PHN) and 2,5-dihydroxybenzoic acid (DHB) were obtained from Sigma (St. Louis, MO). Sequencing grade trypsin (spec. activity: $18800 \mathrm{u} / \mathrm{mg}$ ) was obtained from Promega (Madison, WI), chymotrypsin and pronase from Sigma. Peptide-N-glycosidase F (PNGase F; supplied glycerol free) deglycosylation kits were purchased from Prozyme (San Leandro, CA). Solvents (acetonitrile, ethanol) were HPLC-grade and obtained from Fisher Scientific (Fair Lawn, NJ). HPLC-grade water was obtained with a Milli-Q plus TOC water purification system (Millipore, Bedford, MA).

\section{Release of N-Linked Oligosaccharides from Serum}

Mouse serum $(50 \mu \mathrm{L})$ was first denatured at $95{ }^{\circ} \mathrm{C}$ for 5 min. After cooling to room temperature, serum was digested with trypsin $(10 \mu \mathrm{L})$ and chymotrypsin (50 $\mu \mathrm{g}$ dissolved in $20 \mathrm{mM}$ ammonium bicarbonate) at $37^{\circ} \mathrm{C}$ for $24 \mathrm{~h}$. Then, PNGase F enzyme $(5 \mu \mathrm{L} ; 10 \mathrm{u})$ was added and the total mixture was again incubated at $37{ }^{\circ} \mathrm{C}$ for $24 \mathrm{~h}$. Next, pronase solution $(20 \mu \mathrm{g}$ dissolved in $20 \mu \mathrm{L}$ of $25 \mathrm{mM}$ ammonium bicarbonate) was added to the digested serum and again incubation proceeded for $\sim 10 \mathrm{~h}$ at $37^{\circ} \mathrm{C}$. During the incubation time, the reaction sample was mixed occasionally.

\section{Derivatization of Oligosaccharides in Total Digested Serum}

After enzymatic digestions total serum was heated with phenylhydrazine $(5 \mu \mathrm{L})$ at $70{ }^{\circ} \mathrm{C}$ for $1 \mathrm{~h}$ (mixed periodically during incubation) [29].

\section{RP-HPLC Fractionation of the Treated Serum}

The samples of digested mice sera (native and derivatized) were fractionated and purified on a System Gold HPLC chromatograph equipped with a System Gold 166 UV Detector and 32-Karat software (BeckmanCoulter, Canada, ON, Canada). For RP-HPLC, an analytical column Vydac 218 TP54 C18, 300- $\AA$ pore size, $0.46 \mathrm{~cm} \times 25 \mathrm{~cm}$ (Separation Group, Hesperia, CA) was used. The chromatograph was equipped with a Rheodyne injector (5 $\mu \mathrm{L}$ loop). The samples were eluted with $5 \% \mathrm{ACN}$ in water as Solvent $\mathrm{A}$, and $90 \% \mathrm{ACN}$ in $0.1 \%$ TFA as Solvent B at a flow rate of $0.5 \mathrm{~mL} / \mathrm{min}$. An elution gradient was applied from 5\% to $70 \%$ ACN over $30 \mathrm{~min}$. UV detection was performed at 245 $\mathrm{nm}$. Fractions were collected manually and concentrated in vacuo. Then $30 \% \mathrm{ACN}$ in water $(5 \mu \mathrm{L})$ was added to each dried fraction, mixed, and used for MS analysis.

\section{MALDI-Mass Spectrometric Analysis}

The spots from individual HPLC-fractions were analyzed by MALDI mass spectrometry (MS) and tandem mass spectrometry (MS/MS) on the Manitoba/SCIEX prototype quadrupole-quadrupole-TOF (QqTOF) mass spectrometer [30]. In this instrument, ions are generated irradiation of the sample with photon pulses from a 20 Hz nitrogen laser (VCL 337ND; Spectra-Physics, Mountain View, CA) with $300 \mathrm{~mJ}$ energy per pulse. Parent ions are selected in Q1 after cooling, after which they are broken upon $\mathrm{q} 2$ by collisional-induced dissociation (CID) at low-energy. The collisional energy for each precursor ion $m / z$ value was determined by applying a well-defined accelerating voltage at the entrance of the Q2 and values were around $50 \mathrm{~V}$ per $1000 \mathrm{Da}$. The resulting product ions were measured in the TOF analyzer. Orthogonal injection of ions from the quadrupole into the TOF section routinely produces a mass resolving power of $\sim 10,000 \mathrm{FWHM}$ and accuracy within a few $\mathrm{mDa}$, in both $\mathrm{MS}$ and MS/MS modes.

A saturated matrix solution of 2,5-dihydroxybenzoic acid (DHB) in acetonitrile:water (1:1) was deposited onto the stainless steel MALDI target and analyte solution $(1 \mu \mathrm{L})$ was spotted onto the dried matrix. Then, before each spot dried completely, PHN solution was spotted $(0.5 \mu \mathrm{L} ; 3 \mu \mathrm{L}$ of PHN reagent diluted in $12 \mu \mathrm{L}$ of deionized water and $3 \mu \mathrm{L}$ of $\mathrm{ACN}$ ) and samples were left to dry at $37^{\circ} \mathrm{C}(\sim 30 \mathrm{~min})$. MS/MS spectra of oligosaccharides were interpreted manually and detected structures of common N-glycan were compared with compositions described in previous studies [3133]. For the assignment of all oligosaccharide fragment ions, the general nomenclature established by Domon and Costello was followed [34].

\section{Results and Discussion}

\section{Isolation of N-Linked Oligosaccharides from Serum}

Serum samples obtained from cancerous and healthy mice were first digested with trypsin/chymotrypsin and deglycosylated directly without previous purification from salts or other small components. An additional use of pronase allowed the cleavage of large tryptic peptides/glycopeptides into small species. The enzymatically digested sample was treated with PHN and $10 \mu \mathrm{L}$ of the whole derivatized serum was then purified by HPLC on a reversed-phase column. The HPLC elution conditions used allowed pooling of oligosaccharides (as intended) rather than complete separation of these compounds. HPLC fractions obtained within 10 min were evaporated and spotted with PHN solution (see the Experimental section) to enhance the oligosaccharide ion signals and suppress peaks of peptides present in the mixture [35]. The same separation procedure was applied for underivatized serum (serum fractionated directly after enzymatic digestions without 
previous PHN oligosaccharides derivatization). Fractions were analyzed in both their native form and after adding PHN solution (oligosaccharides were collected within early fractions, $2.5-4 \mathrm{~min}$ ). This variant of the procedure was more suitable for pooling oligosaccharides with three and more sialic acids on the antennae.

Generally, three fractions of oligosaccharides were obtained (eluted by $\sim 10 \% \mathrm{ACN}$ ). The first fraction was copious in oligosaccharides with three and more sialic acids on the nonreducing chains. The composition was very comparable in both types of serum (Figure 1a). The second fraction (Figure $1 \mathrm{~b}$ and c) contained abundant neutral complex, galactosylated and mono/disialylated structures. High-mannose glycans $(\mathrm{m} / \mathrm{z}$ 1347.5, 1509.5, 1671.6) were observed in the spectra recorded from the cancer sera (Figure 1d). Peaks observed in all spectra as N-linked glycans and identified in both types of sera are listed in Table 1. Typically, all neutral glycans produced only $[\mathrm{M}+\mathrm{Na}]^{+}$ions. Sialylated oligosaccharides provided additional sodiated $[\mathrm{M}-(\mathrm{n}-1) \mathrm{H}+\mathrm{nNa}]^{+}$ions depending on the $(n-1)$ number of sialic acid residues in the molecule. Multisodiated ions provided more complicated MS/MS fragmentation patterns, however, produced fragment ions containing the acidic residues, important for determination of sialic acid position in the molecule.

Furthermore, we observed peaks that according to their $m / z$ values were not consistent with typical oligosaccharide compositions. On the basis of MALDIMS/MS analyses, we found that these peaks corresponded also to carbohydrate structures containing noncharacteristic residues.

\section{MALDI-MS/MS Characterization of N-Linked Glycans}

To verify the composition and obtain structural information about oligosaccharide peaks observed in direct mass spectra, a number of ions were subjected to tandem analysis. Some structures of interest are concisely discussed below.

High-mannose glycans. The abundant precursor ions detected at $m / z$ 1347.5, 1509.5, and 1671.6 (Figure 1d) produced identical MS/MS fragmentation patterns. B, C-fragment ions resulted from the loss of chitobiose core and were consistent with a composition of highmannose glycans (Figure 2a). The loss of 3-positioned hexose(s) from these fragment ions appeared at $\mathrm{m} / \mathrm{z}$ $671.2\left(B_{3} / Y_{3 \beta}\right)$. These ions underwent the characteristic subsequent loss of water detected at $m / z 653.2$ [31, 32]. A-cross-ring cleavage ions of the reducing terminal GlcNAc $(m / z$ 1069.4, 1258.5, 1318.5) were consistent with the cleavage of the chitobiose core.

Hybrid glycans. The glycans detected at $m / z 1550.5$ and 1712.7 in cancer sera $\left([\mathrm{M}+\mathrm{Na}]^{+}\right.$parent ions, Figure $\left.1 \mathrm{c}\right)$, could be recognized as hybrid-type structures. B/Y- ions observed at $\mathrm{m} / \mathrm{z} 671.2$ and 653.5 were consistent with the loss of chitobiose core and monosaccharide residues from the 3-linked arm of the core mannose (Figure $2 b$ ). Fragment ions at $m / z 833.3$ corresponding to a $(\mathrm{Hex})_{5}$ residue were produced from $\mathrm{B}_{4}\left(\mathrm{C}_{4}\right)$ ions by loss of 162 and $203 \mathrm{u}$.

Sialylated glycans. The PHN-glycan detected at $\mathrm{m} / \mathrm{z}$ 2041 as $[\mathrm{M}-\mathrm{H}+2 \mathrm{Na}]^{+}$was consistent again with a not very common hybrid structure (described above) in which sialic acid is linked to galactose on the 3-arm (Figure 3a). $\mathrm{Y}_{6}$ fragment ions at $\mathrm{m} / \mathrm{z} 1712.5$ corresponded to the loss of a single neuraminic acid (307 u). Disodiated $C_{4 \alpha}$ fragment ions detected at $m / z 897.2$ were consistent with the N-glycolyl-neuraminic acid linked to galactose on the 3-antenna. PHN-oligosaccharides with $[\mathrm{M}+\mathrm{Na}]^{+}$ions at $m / z 2206.7$ (Table 1) corresponded to a mono sialylated structure with fucose linked at the labeled GlcNAc-fragment ions detected at $m / z 1771.6\left(\mathrm{~B}_{6}\right), 1787.6\left(\mathrm{C}_{6}\right)$, and 1584.5 $\left(\mathrm{C}_{5}\right)$. Disodiated precursors at $\mathrm{m} / \mathrm{z} 2228.7([\mathrm{M}-\mathrm{H}+$ $2 \mathrm{Na}]^{+}$) produced cross-ring cleavage ions at $\mathrm{m} / \mathrm{z}$ $1831.5\left({ }^{2,4} \mathrm{~A}_{7}\right)$, consistent with fucose being linked at the 6-position of the reducing-terminal GlcNAc residue. The same type of fucosylation was found in the neutral analog of this glycan with parent ions at $\mathrm{m} / \mathrm{z}$ $1899.8\left({ }^{2,4} \mathrm{~A}_{7}\right.$ cross-ring ions appeared at $m / z$ 1502.6). Disialylated oligosaccharides at $m / z 2513.9$ ([M + $\mathrm{Na}^{+}$) produced fragment ions again consistent with the presence of fucose at the reducing-terminus. In the spectrum of multisodiated $[\mathrm{M}-2 \mathrm{H}+3 \mathrm{Na}]^{+}$ parent ions $(m / z$ at 2557.9$),{ }^{2,4} \mathrm{~A}_{7}$ cross-ring cleavages were observed at $m / z 2160.5$, consistent with fucose being linked to the 6-position of the labeled core GlcNAc residue. In the MS spectra of both types of sera, abundant $[\mathrm{M}+\mathrm{Na}]^{+}$peaks detected at $\mathrm{m} / \mathrm{z}$ 2674.9 and $[\mathrm{M}-\mathrm{H}+2 \mathrm{Na}]^{+}$at $m / z 2696.9$ indicated a trisialylated biantennary structure (Figure $3 b$ ). The loss of three sialic acids produced abundant fragment ions at $m / z$ 1753.7. The cross-ring ${ }^{1,5} \mathrm{X}_{4}$ fragments from the 6-arm $(m / z$ 1891.6) indicated two sialic acids linked at the 3-arm. The MS/MS spectrum recorded for precursor $[\mathrm{M}+\mathrm{Na}]^{+}$ions at $\mathrm{m} / \mathrm{z} 3039.8$ corresponded to a triantennary oligosaccharide with sialic acid on each arm. This structure was also consistent with $[\mathrm{M}+\mathrm{Na}]^{+}$ions detected at $m / z 3185.9$ indicating the presence of fucose (Figure 3c). Fragmentation of parent ions at $m / z 3347.1$ was consistent with a triantennary glycan as described above at $\mathrm{m} / \mathrm{z} 3039.8$ in the addition of sialic acid more (four sialic acid moieties; Table 1). The $Z_{3}$ fragment ions detected at $\mathrm{m} / \mathrm{z} \quad 2190.8$ corresponded to the loss of (SA) $)_{2}$ GalGlcNAcMan from the 3 -arm of the core mannose. No fragment ions were produced to support the presence of two sialic acids on one of the 6-arms. 

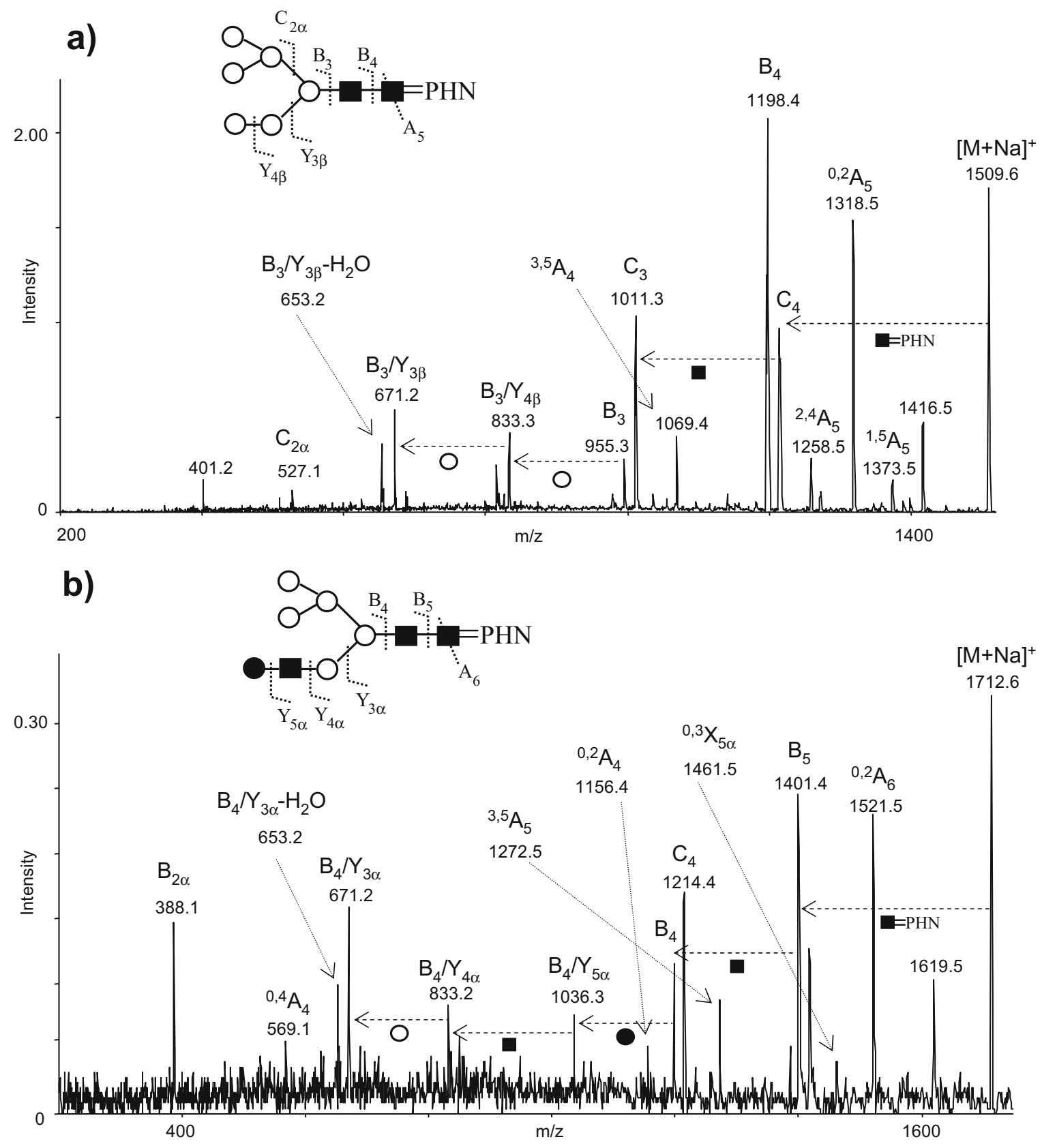

Figure 2. MALDI-MS / MS spectra of glycans recorded with the QqTOF mass spectrometer from mice sera, precursor ions at $m / z$ : (a) $1509.6[\mathrm{M}+\mathrm{Na}]^{+}$, tumor serum; (b) $1712.6[\mathrm{M}+\mathrm{Na}]^{+}$, tumor serum. For symbols see Figure 1.

\section{MALDI-MS/MS Characterization of Uncommon Glycoforms}

Peaks observed at $m / z 1200.4,1362.5,1565.6,1727.7$, and 2034.7 (Table 2) were assigned as $[\mathrm{M}+\mathrm{H}]^{+}$ions of sialylated oligosaccharides. Characteristic of these species was the absence of reducing terminus (resistance to PHN-derivatization signaled the absence of free carbonyl reducing-terminus). Instead, the dehydrated form of monosaccharide residue terminated this unusual glycan. These nonderivatizable saccharides produced isobaric fragment ions, which resulted in complicated ambiguous fragmentations for determination struc- tures. Generally, the loss of sialic acid ( $307 \mathrm{u}$ ) appeared as Y-type fragment ions comprised of hexose and $\mathrm{N}$-acetylhexosamine residues (Figure 4). In all spectra the abundant fragment ions at $m / z 673.23$ were consistent with B-type ions of composition NeuGc-Hex-HexNAc.

According to the fragmentation pattern observed in the tandem mass spectrum of a glycan with precursor ions at $\mathrm{m} / \mathrm{z} 1200.4$ (Figure $4 \mathrm{a}$ ), the loss of $203 \mathrm{u}$, which produced fragment ions at $\mathrm{m} / \mathrm{z} 997.3\left(\mathrm{~B}_{4}\right)$ or $1015.3\left(\mathrm{C}_{4}\right)$, signalized HexNAc dehydrated form instead of the usual residue with a reducing terminus. A small peak at $\mathrm{m} / \mathrm{z}$ 1038.3, which corresponded to the direct loss of 

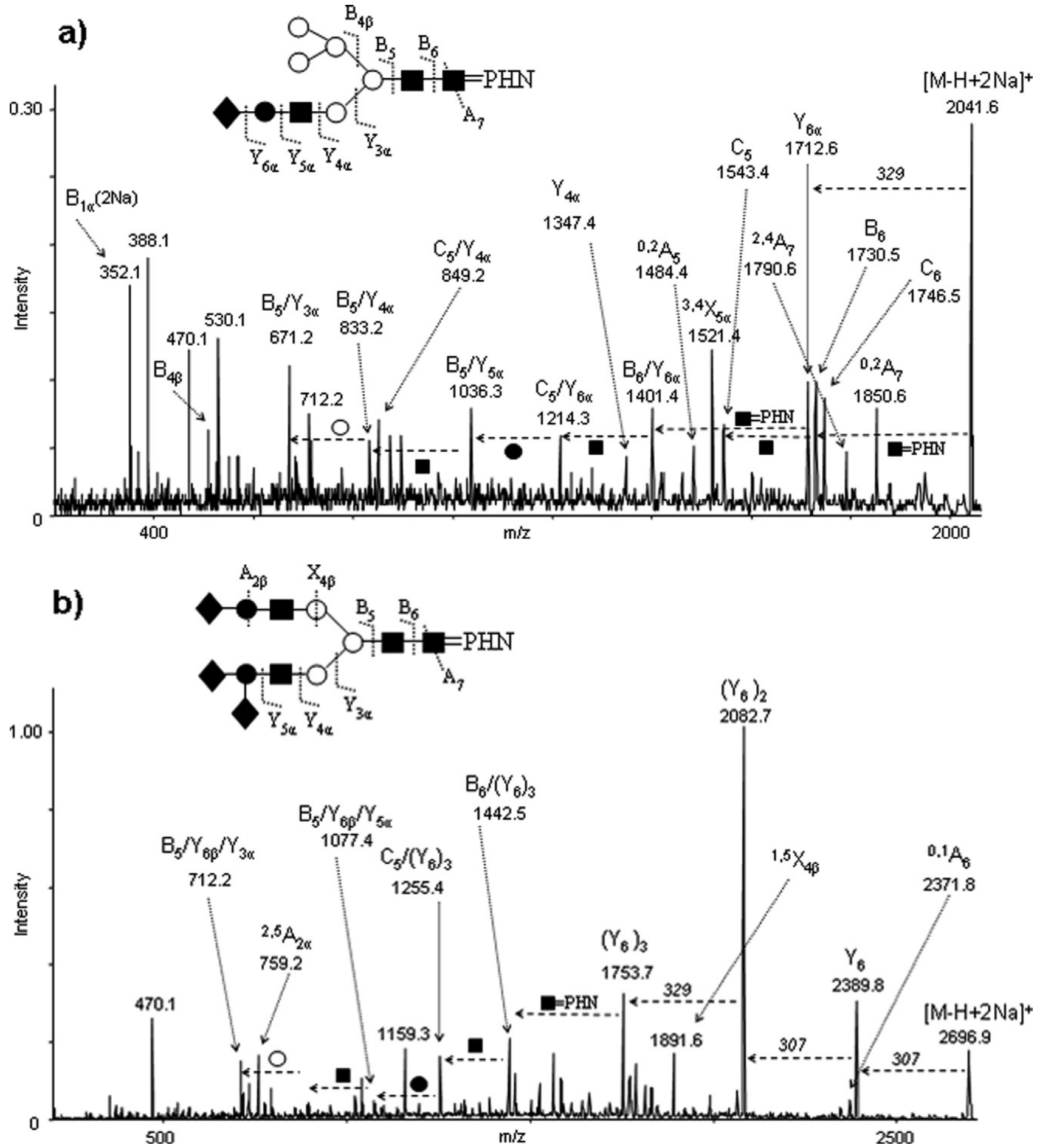

Figure 3. MALDI-MS/MS spectra of sialylated glycans recorded from (a) $2041.6[\mathrm{M}-\mathrm{H}+2 \mathrm{Na}]^{+}$, tumor serum; (b) $2696.9[\mathrm{M}-\mathrm{H}+2 \mathrm{Na}]^{+}$, healthy serum; (c) $3185.9[\mathrm{M}+\mathrm{Na}]^{+}$, healthy serum. For symbols see Figure 1.

$162 \mathrm{u}$ from parent ions and fragment ions detected at $\mathrm{m} / \mathrm{z} 569.2$ consistent with Hex-(HexNAc) ${ }_{2}$ composition residue, was highly correlated to the structure depicted in Figure 4a.

Precursor ions at $m / z 1362.5$ (Figure 4b) lost additional $162 \mathrm{u}(\mathrm{m} / \mathrm{z}$ 1200.4). For this oligosaccharide two main structures were derived from MS/MS data. How- ever, ions at $m / z 569.2$ could be signed only to the Isomer 2.

Oligosaccharide with precursor $[\mathrm{M}+\mathrm{H}]^{+}$ions detected at $\mathrm{m} / \mathrm{z} 2034.7$ (Figure 4c) produced fragment ions consistent with an additional NeuGc-Hex-HexNAc-Hex residue $\left(\mathrm{Y}_{5 \alpha}\right.$ at 1727.7, $\mathrm{Y}_{4 \alpha}$ at 1565.6, $\mathrm{Y}_{3 \alpha}$ at 1362.5, $\mathrm{Y}_{2 \alpha}$ at 1200.4, Isomer 1). Fragment ions observed at $m / z$ 1872.6, 


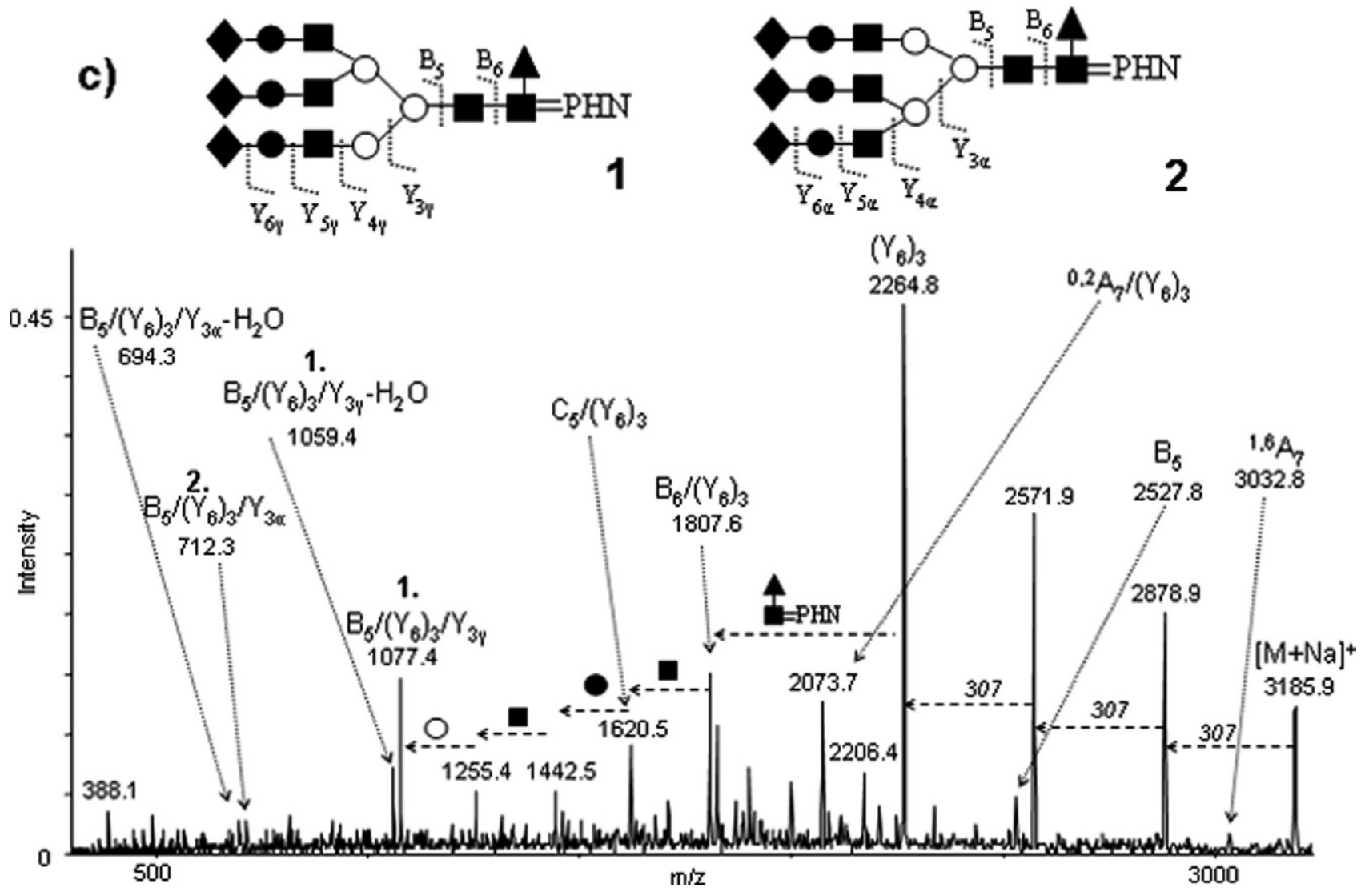

Figure 3. Continued

1831.6, 1669.6, and 1304.4 corresponded only to the losses of neutral monosaccharide residues and could be assigned to both Isomers $\mathbf{1}$ and 2, with two sialic acids occupying only one antenna (Figure $4 \mathrm{c}$ ). Here again, a small ion peak at $m / z 569.2$ favored the Isomer 2 . In the MS/MS spectra of these glycoforms, relatively high peaks observed at $m / z 204.08$ and lower, matched to those observed in the tandem mass spectra recorded for $[\mathrm{M}+\mathrm{H}]^{+}$ions of native and derivatized disaccharide Gal(1-4)GlcNAc or in the study of per-O-methylated protonated oligosaccharides [36].

Ion peaks detected at $m / z$ 2016.7, 2162.8, 2345.9, and 2491.9 corresponded to labeled oligosaccharides in addition $60 \mathrm{u}$ more (Table 2). For example, the $[\mathrm{M}+\mathrm{Na}]^{+}$ parent ions at $\mathrm{m} / \mathrm{z} 2016.7$ indicated a derivatized oligosaccharide, $\mathrm{Hex}_{5} \mathrm{GlCNAc}_{5} \mathrm{PHN}$ with an extra $60 \mathrm{Da}$ (before derivatization this oligosaccharides was detected at $\mathrm{m} / \mathrm{z}$ 1926.7). Based on the MS/MS fragmentation pattern, two isomers were suggested (Figure 5). Characteristic fragments associated with the loss of PHN-labeled reducing-terminal GlcNAc appeared at $\mathrm{m} / \mathrm{z} 1705.6\left(\mathrm{~B}_{5}\right)$ and $1518.5\left(\mathrm{C}_{4}\right)$. Isomer $\mathbf{1}$ produced distinctive ions at $\mathrm{m} / \mathrm{z}$ 1077.4, indicating the loss of $60 \mathrm{u}$ from a GlcNAc residue at the 3-arm of the core mannose. The loss of GlcNAc and Hex residues produced abundant ions at $m / z 712.2\left(B_{5} / Y_{3 \alpha}\right)$, associated with the loss of water $(m / z$ 694.2). Abundant ions detected at $m / z$ $975.4\left(\mathrm{~B}_{5} / \mathrm{Y}_{3 \gamma}\right)$ with the subsequent loss of water at $\mathrm{m} / \mathrm{z}$
957.3 were consistent with Isomer 2. As discussed above, the reducing GlcNAc residue was labeled with phenylhydrazine and appeared as the loss of $311 \mathrm{u}$ followed by the loss of $203 \mathrm{u}$ (overall the loss of chitobiose core), the characteristic fragment ions observed in the MS/MS spectra of all PHN-glycans. Thus the 60 increment is part of or linked to a nonreducing GlcNAc moiety on one antenna. The possibility of incorporation of a mass 60 residue into a HexNAc moiety (the existence of $\mathrm{N}$-acetyl-octosamine, Scheme 1) on the antenna of the core mannose can be supported by other ions observed in Figure 5. Fragment ions

Table 2. Uncommon oligosaccharides detected in mice serum

\begin{tabular}{lcl}
\hline $\begin{array}{c}\text { Parent ion } \mathrm{m} / \mathrm{z} \\
\text { (observed) }\end{array}$ & $\begin{array}{c}\text { Mr } \\
\text { (calculated) }\end{array}$ & Composition (MALDI-MS/MS) \\
\hline \hline $1200.4^{*}$ & 1199.4 & $\mathrm{Hex}_{3} \mathrm{HexNAc}_{2} \mathrm{SA}$ \\
$1362.5^{*}$ & 1361.5 & $\mathrm{Hex}_{4} \mathrm{HexNAc}_{2} \mathrm{SA}$ \\
$1565.6^{*}$ & 1564.6 & $\mathrm{Hex}_{4} \mathrm{HexNAc}_{3} \mathrm{SA}$ \\
$1727.7^{*}$ & 1726.7 & $\mathrm{Hex}_{5} \mathrm{HexNAc}_{3} \mathrm{SA}$ \\
$2034.7^{*}$ & 2033.7 & $\mathrm{Hex}_{5} \mathrm{HexNAc}_{3} \mathrm{SA}{ }_{2}$ \\
$2016.7+$ & 1993.7 & $\mathrm{Hex}_{5} \mathrm{HexNAc}_{5} \mathrm{PHN}+60$ \\
$2162.8+$ & 2139.8 & $\mathrm{Hex}_{5} \mathrm{HexNAc}_{5} \mathrm{FucPHN}+60$ \\
$2345.9++$ & 2300.9 & $\mathrm{Hex}_{5} \mathrm{HexNAc}_{5} \mathrm{SAPHN}+60$ \\
$2491.9++$ & 2446.9 & $\mathrm{Hex}_{5} \mathrm{HexNAc}_{5} \mathrm{FucSAPHN}+60$
\end{tabular}

* Ions observed corresponded to $\left[\mathrm{M}-\mathrm{H}_{2} \mathrm{O}+\mathrm{H}\right]^{+}$.

${ }^{+}$Ions observed corresponded to $[\mathrm{M}+\mathrm{Na}]^{+}$.

${ }^{++}$Ions observed corresponded to $[\mathrm{M}-\mathrm{H}+2 \mathrm{Na}]^{+}$. 

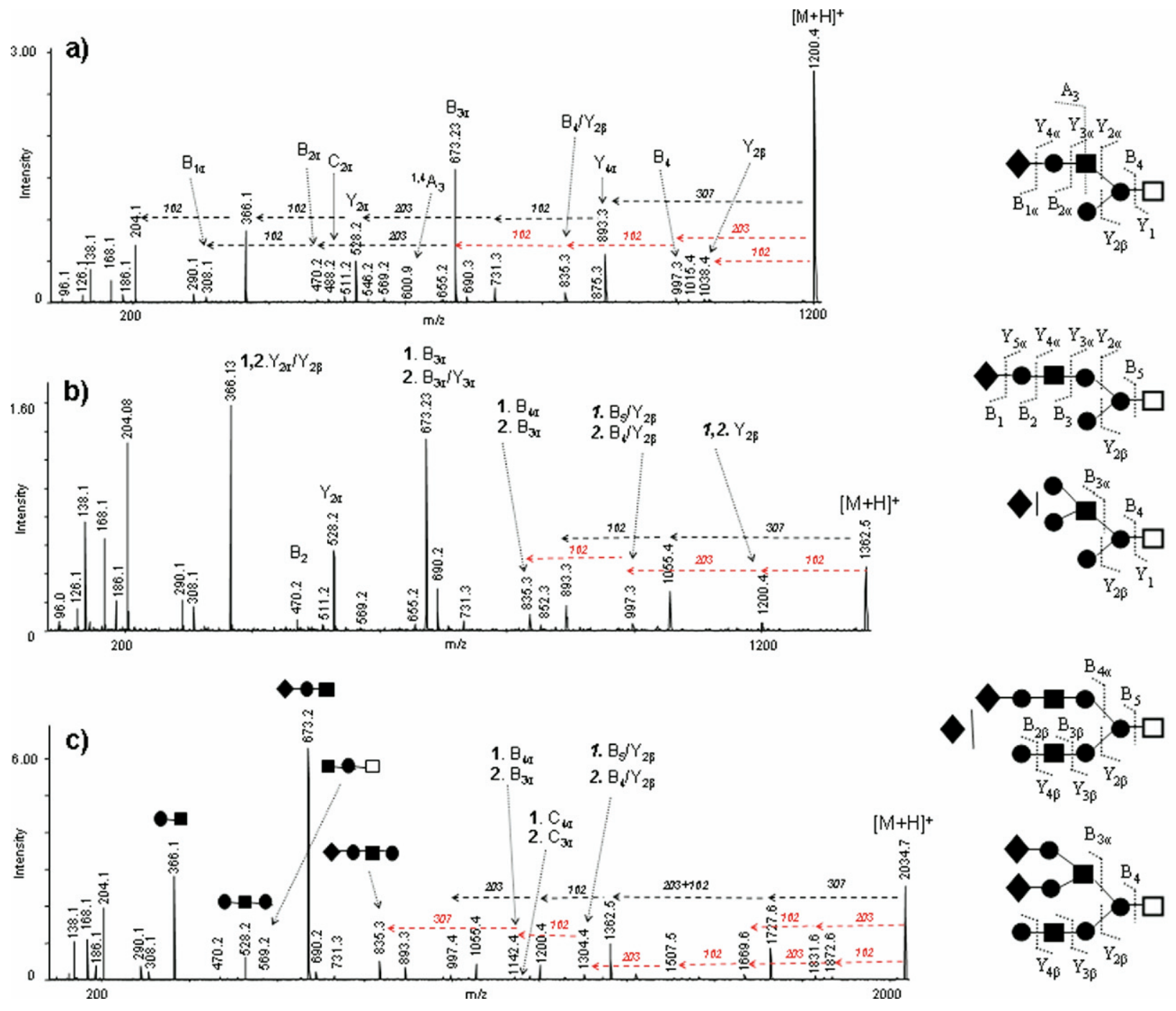

Figure 4. MALDI-MS/MS spectra and suggested structure of glycans recorded from mouse serum with the QqTOF mass spectrometer with $[\mathrm{M}+\mathrm{H}]^{+}$precursor ions at: (a) $\mathrm{m} / \mathrm{z} 1200.4$, (b) $\mathrm{m} / \mathrm{z} 1362.5$, and (c) $\mathrm{m} / \mathrm{z}$ 2034.7. The important fragment pathways for determination of the suggested structures are emphasized by red color. Symbols: (filled circle) Hex; (filled square) HexNAc; (open square) $\operatorname{HexNAc}\left(-\mathrm{H}_{2} \mathrm{O}\right)$; (filled diamond) NeuGc.

observed at $\mathrm{m} / \mathrm{z} 1753.6$ correspond to the loss of 263 from the parent ion. Fragment ions that appeared as relatively high peaks at $\mathrm{m} / \mathrm{z} 414.1,448.1$, and 464.1 are most probably associated with a Hex-GlcNAc(+60) residue (Scheme 1). These ions were not observed in the MS/MS spectra of common N-linked oligosaccharides (unpublished results).

To rule out the possibility that the above discussed oligosaccharide structures with uncommon residue were produced during sample preparation, other types of treated or untreated samples were compared. In our experience, commercial sources (e.g., bovine), glycoproteins (ovalbumin, transferrin, IgG) were digested, treated, and fractionated under the same conditions corresponding to those listed here in the experimental part. Those other samples never showed the presence of uncommon oligosaccharides forms. Also in our laboratory, numerous experiments of derivatization with
PHN show that the reagent did not cleave glycans or monosaccharide units to small molecules. Those unusual oligosaccharides were already present in serum before PHN and/or enzymatic treatment.

\section{Distinctive Differences Observed in Oligosaccharides from Serum Samples}

The major distinction between oligosaccharides in serum samples isolated from several tumoral and healthy mice (representative example shown in Figure 1) was the presence of high-mannose oligosaccharides, which appeared as more abundant ions at $m / z 1347,1509$, and 1671 in tumoral samples. Also, glycans with no GlcNAc residue at the 6-positioned core mannose (hybrid glycans, $m / z$ at $1550.5,1712.6$, including not very common sialylated structure of $m / z$ 2019.7) were detected only in 


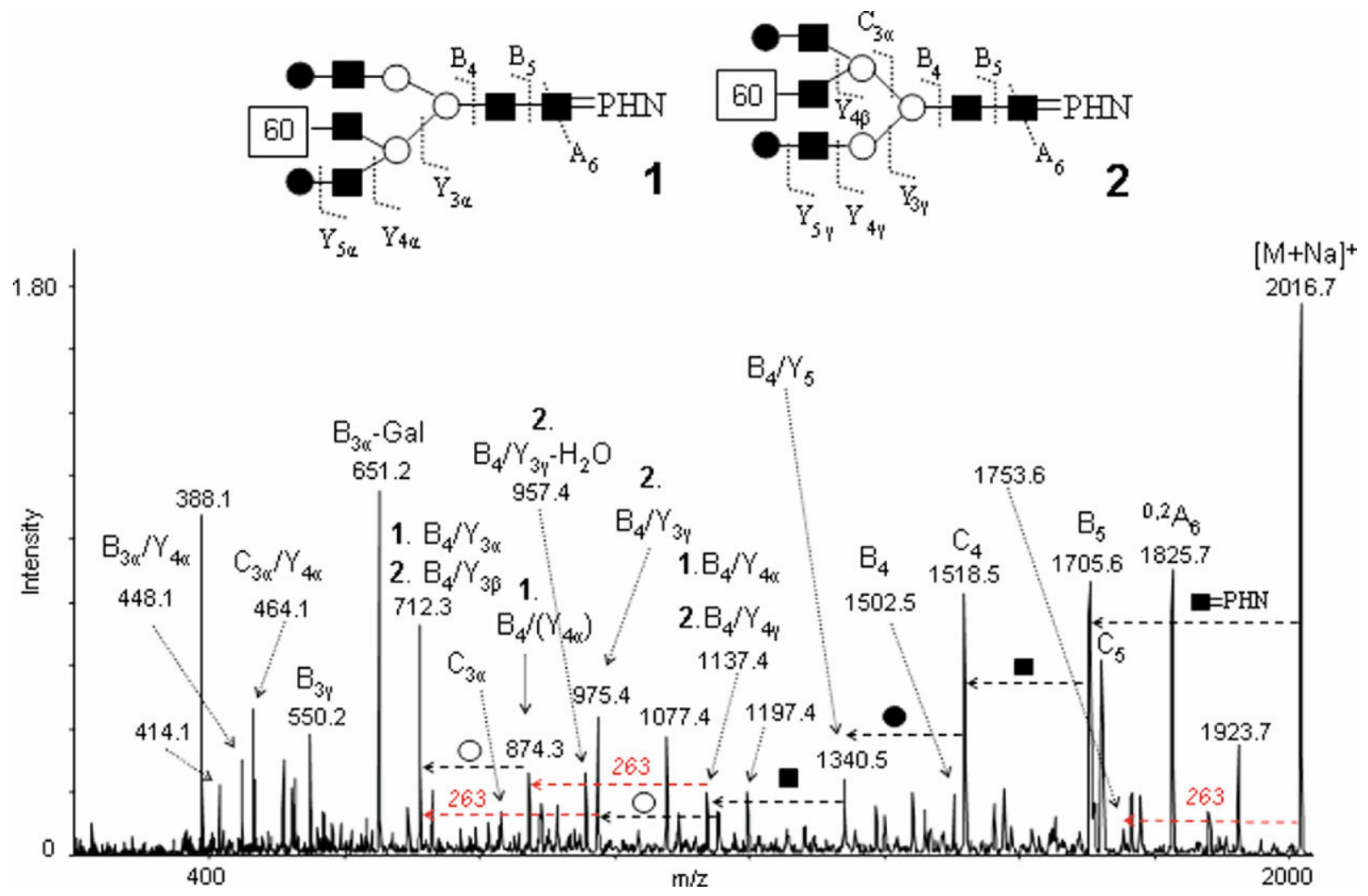

Figure 5. MALDI-MS/MS spectrum of a glycan recorded from healthy mouse serum with the QqTOF mass spectrometer for $[\mathrm{M}+\mathrm{Na}]^{+}$precursor ions at $\mathrm{m} / z$ 2016.7. All ions are sodium cationized. For symbols see Figure 1.

the sera obtained from mice with tumors. Precursor ions at $\mathrm{m} / \mathrm{z} 1712.7$ were also detected in some healthy samples. However, the MS/MS pattern did not indicate an oligosaccharide composition. The higher occurrence of high mannose and hybrid glycans in cancer sera could support the hypothesis that tumor cell surface glycoconjugates terminated by mannose or N-acetylglucosamine residues are attacked by cells of the innate immune network [37] and macrophages [38], which have receptors for these carbohydrate residues.

$\mathrm{N}$-glycans with a bisecting GlcNAc residue were generally very minor in abundance and observed mostly in the sera of tumoral mice. The same differences were observed in the study of sera of cirrhotic patients [26]. Increased levels of 6-linked fucose are often associated with cancer [25, 39]. In our study, 6-O-linked fucose residue on the reducing GlcNAc was found in healthy and cancer samples, however in higher abundances in cancer sera (at $\mathrm{m} / \mathrm{z}$ 1899.7, 2228.7, and 2557.8).

Complex sialylated $\mathrm{N}$-glycans showed very similar abundances in both types of serum. Only one major difference was observed: disialylated fucosylated glycans $\left(\mathrm{m} / \mathrm{z} 2513.9\right.$ for $[\mathrm{M}+\mathrm{Na}]^{+}$ions, or 2557.8 for [M $2 \mathrm{H}+3 \mathrm{Na}]^{+}$ions), were considerably more abundant in tumoral than in healthy samples.

The carbohydrates of uncommon composition (sialylated with dehydro-HexNAc residue in the end of chain and those with the extra 60 units increment) were detected in both type samples, however showed higher abundances in control serum samples.

\section{Conclusions}

Serum samples were obtained from cancerous and healthy mice and PNGase was used to release N-linked glycans. A combination of PHN derivatization and MALDI-MS was implicated in the analyses of these glycans. The representative pools of labeled carbohydrates comprised more than $40 \mathrm{~N}$-glycan structures of high-mannose, hybrid, and complex compositions. Asialo and sialylated oligosaccharides were analyzed from the same spot. MALDI-MS/MS spectra provided important insights towards the determination of structures of neutral and acidic glycans, and known struc-

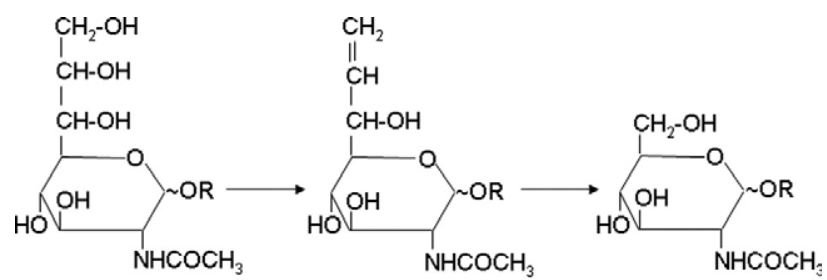

$m / z 448.1$ $\mathrm{m} / \mathrm{z} 388.1$

Scheme 1 
tures agreed well with compositions found in previous studies. The major differences between tumoral and healthy sera were observed in the content of highmannose glycans and oligosaccharides without GlcNAc linked on the 6-positioned mannose (hybrid glycans). These glycans were distinctly more abundant in cancer sera. Furthermore, in this study we did not observe significant changes in the sialylation of complex oligosaccharides between cancerous and healthy sera. Mostly all fucosylated glycans showed a 6-linked fucose at the reducing termini in glycans of both serum types, however with higher abundances of these oligosaccharides in cancerous serum.

The present study further confirms the presence of oligosaccharides with uncommon compositions. Several sialylated dehydrated oligosaccharides with no free reducing end in the chain were detected in the sera. In spite of MS/MS fragmentation patterns isobaric for more possible structures, a few small ion peaks were critical to assign the suggested structures. Biantennary glycans with extra 60 units seem to bear a 2-acetamido2-deoxyoctose residue linked to a nonreducing mannose in biantennary glycans. Confirmation of these uncommon glycans by other analytical methods was not possible due to their low abundances in the sample analyzed. Nonetheless, the consistent and reproducible MS/MS data provided a good level of confidence for the presence of these structures. In addition, the comparison of fragmentation patterns of uncommon structures with those of known glycans, analyzed in both native and derivatized forms, gave a good basis to suggest the novel glycoforms observed in this study.

\section{Acknowledgments}

The authors acknowledge Vic Spicer for technical assistance with the MALDI instrument. They also acknowledge Professors Kenneth G. Standing and Werner Ens for the use of the Qq-TOF mass spectrometer. The authors thank Dr. G. Thorne-Tjomsland and Professor James C. Jamieson for helpful discussion, and Mr. Wayne Buchannon for technical support. This work was supported by grants from the Natural Sciences and Engineering Research Council of Canada (NSERC), from the Canadian Foundation for Innovation (CFI), and the Canada Research Chairs Program (CRC).

\section{References}

1. Varki, A., Evolution of Glycan Diversity. In Essentials of Glycobiology, Varki, A.; Cummings, R.; Esko, J.; Freeze, H.; Hart, G.; Marth, J. Eds.; Book News Inc: Portland, OR, 1999; pp 31-37.

2. Mungul, A.; Cooper, L.; Brockhausen, I.; Ryder, K.; Mandel, U.; Clausen, H.; Rughetti, A.; Miles, D. W.; Taylor-Papadimitriou, J.; Burchell, J. M. Sialylated Core 1 Based O-Linked Glycans Enhance the Growth Rate of Mammary Carcinoma Cells in MUC1 Transgenic Mice. Int. J. Oncol. 2004, 25, 937-943.

3. Ravindranath, M. H.; Yesowitch, P.; Sumobay, C.; Morton, D. L. Glycoimmunomics of Human Cancer: Current Concepts and Future Perspectives. Future Oncol 2007, 3, 201-214

4. Kobata, A.; Amano, J. Altered Glycosylation of Proteins Produced by Malignant Cells, and Application for the Diagnosis and Immunotherapy of Tumors. Immunol. Cell Biol. 2005, 83, 429-439.

5. Hakomori, S. Inaugural Article: The Glycosynapse. Proc. Nat. Acad. Sci. U.S.A. 2002, 99, 225-232.
6. Durand, G.; Seta, N. Protein Glycosylation and Diseases: Blood and Urinary Oligosaccharides as Markers for Diagnosis and Therapeutic Monitoring. Clin. Chem. 2000, 46, 795-805.

7. Hakomori, S. Tumor-Associated Carbohydrate Antigens Defining Tumor Malignancy: Basis for Development of Anticancer Vaccines. Adv. Exp. Med. Biol. 2001, 491, 369-402.

8. Dennis, J. W. Changes in Glycosylation Associated with Malignant Transformation and Tumor Progression. In: Cell Surface Carbohydrates and Cell Development, Fukuda, M., Ed.; CRC Press: London 1995; pp 161-194.

9. Dabelsteen, E. J. Cell Surface Carbohydrates as Prognostic Markers in Human Carcinomas. Pathology 1996, 179, 358-369.

10. Karas, M.; Hillenkamp F. Laser Desorption Ionization of Proteins with Molecular Masses Exceeding 10,000 Daltons. Anal. Chem. 1988, 60, $2299-2301$

11. Tanaka, N.; Waki, H.; Ido, Y.; Akita, S.; Yoshida, Y.; Yoshida, T. Protein and Polymer Analyses Up to m/z 100000 by Laser Ionization Time-ofFlight Mass Spectrometry. Rapid Commun. Mass Spectrom. 1988, 2 151-153.

12. Harvey, D. J. Identification of Protein-Bound Carbohydrates by Mass Spectrometry. Proteomics 2001, 1, 311-328.

13. Mechref, Y.; Novotny, M. Structural Investigations of Glycoconjugates at High Sensitivity. Chem. Rev. 2002, 102, 321-369.

14. Zaia, J. Mass Spectrometry of Oligosaccharides. Mass Spectrom. Rev. 2004, 23, 161-227

15. Šagi, D.; Kienz, P.; Denecke, J.; Marguardt, T.; Katalanić, J. P. Glycoproteomics of N-Glycosylation by In-Gel Deglycosylation and MatrixAssisted Laser Desorption/Ionization Time-of-Flight Mass Spectrometry Mapping: Application to Congenital Disorders of glycosylation. Proteomics 2005, 5, 2689-2701.

16. Papac, D. J.; Wong, A.; Jones, A. J. S. Analysis of Acidic Oligosaccharides and Glycopeptides by Matrix-Assisted Laser Desorption/Ionization Time-of-Flight Mass Spectrometry. Anal. Chem. 1996, 68, 3215-3223.

17. Zhang, J.; Lindsay, L. L.; Hedrick, J. L.; Lebrilla, C. B. Strategy for Profiling and Structure Elucidation of Mucin-Type Oligosaccharides by Mass Spectrometry. Anal. Chem. 2004, 76, 5990-6001.

18. Zhao, J.; Simeone, D. M.; Heidt, D.; Anderson, M. A.; Lubman, D. M. Comparative Serum Glycoproteomics Using Lectin Selected Sialic Acid Glycoproteins with Mass Spectrometric Analysis: Application to Pancreatic Cancer Serum. J. Proteome Res. 2006, 5, 1792-1802.

19. Powell, A. K.; Harvey, D. J. Stabilization of Sialic Acids in N-Linked Oligosaccharides and Gangliosides for Analysis by Positive Ion MatrixAssisted Laser Desorption/Ionization Mass Spectrometry. Rapid Commun. Mass Spectrom. 1996, 10, 1027-1032.

20. Karlsson, N. G.; Karlsson, H.; Hansson, G. C. Strategy for the Investigation of O-Linked Oligosaccharides from Mucins Based on the Separation Into Neutral, Sialic Acid-, and Sulfate-Containing Species. Glycoconj. J. 1995, 12, 69-76.

21. Sekiya, S.; Wada, Y.; Tanaka, K. Derivatization for Stabilizing Sialic Acids in MALDI-MS. Anal. Chem. 2005, 77, 4962-4968.

22. Block, T. M.; Comunale, M. N.; Lowman, M.; et al. Use of Targeted Glycoproteomics to Identify Serum Glycoproteins that Correlate with Liver Cancer in Woodchucks and Humans. Proc. Natl. Acad. Sci. U.S.A. 2005, 102, 779-784.

23. Morelle, W.; Flahaut, C.; Michalski, J. C.; Louvet, A.; Mathurin, P.; Klein A. Mass Spectrometric Approach for Screening Modifications of Total Serum. N-Glycome in Human Diseases: Application to Cirrhosis. Glycobiology 2006, 16, 281-293.

24. Zhao, J.; Qiu, W.; Simeone, D. M.; Heidt, D.; Lubman, D. M. N-Linked Glycosylation Profiling of Pancreatic Cancer Serum Using Capillary Liquid Phase Separation Coupled with Mass Spectrometric Analysis. J. Proteome Res. 2007, 6, 1126-1138.

25. An, J. H.; Miyamoto, S.; Lancaster, K. S.; Kirmiz, C.; Li, B.; Lam, K. S.; Leiserowitz, G. S.; Lebrilla, C. B. Profiling of Glycans in Serum for the Discovery of Potential Biomarkers for Ovarian Cancer. J. Proteome Res. 2006, 5, 1626-1635.

26. American Cancer Society, Cancer Facts and Figures 2007, Atlanta, GA, U.S.A. 2007.

27. Bolot, G.; David, M. J.; Taki, T.; Handa, S.; Kasama, T.; Richard, M.; Pignant, J. C.; Thomas, L.; Portoukalian, J. Analysis of Glycosphingolipids of Human Head and Neck Carcinomas with Comparison to Normal Tissue. Biochem. Mol. Biol. Int. 1998, 46, 125-135.

28. Noda, I.; Fujieda, S.; Seki, M.; Tanaka, N.; Sunaga, H.; Ohtsubo, T.; Tsuzuki, H.; Fan, G. K.; Saito, H. Inhibition of N-Linked Glycosylation by Tunicamycin Enhances Sensitivity to Cisplatin in Human Head-andNeck Carcinoma Cells. Int. J. Cancer 1999, 80, 279-284.

29. Lattová, E.; Kapková, P.; Krokhin, O.; Perreault, H. Method for Investigation of Oligosaccharides from Glycopeptides: Direct Determination of Glycosylation Sites in Proteins. Anal. Chem. 2006, 16, 2977-2984.

30. Loboda, A. V.; Krutchinsky, N. N.; Bromirski, M. P.; Ens, W.; Standing, K. G. A Tandem Quadrupole/Time-of-Flight Mass Spectrometer with a Matrix-Assisted Laser Desorption/Ionization Source: Design and Performance. Rapid Commun. Mass Spectrom. 2000, 14, 1047-1057.

31. Harvey, D. J; Bateman, R. H.; Green, M. R. High-Energy CollisionInduced Fragmentation of Complex Oligosaccharides Ionized by $\mathrm{Ma}-$ trix-Assisted Laser Desorption/Ionization Mass Spectrometry. J. Mass Spectrom. 1997, 32, 167-187.

32. Lattová, E.; Krokhin, O.; Perreault, H. Matrix-Assisted Laser Desorption/ Ionization Tandem Mass Spectrometry and Post-Source Decay Fragmentation Study of Phenylhydrazones of N-Linked Oligosaccharides from Ovalbumin. J. Am. Chem. Soc. Mass Spectrom. 2004, 15, 725-735. 
33. Harvey, D. J; Wing, D. R.; Küster, B.; Wilson, I. B. H. Composition of N-Linked Carbohydrates from Ovalbumin and Copurified Glycoproteins. J. Am. Chem. Soc. Mass Spectrom. 2000, 11, 564-571.

34. Domon, B.; Costello, C. E. A Systematic Nomenclature for Carbohydrate Fragmentations in FAB-MS/MS Spectra of Glycoconjugates. Glycoconj. J. 1988, 5, 397-409.

35. Lattova, E.; Krokhin, O.; Wilkins, J.; Perreault, H. A Comparison of Derivatization Procedures for Mass Spectrometric Analysis of Carbohydrates. Proceedings of the 52nd ASMS Conference on Mass Spectrometry and Allied Topics, Nashoille, TN, May 2004

36. Brull, L. P.; Kováčik, V.; Thomas-Oates, J. E.; Heerma, W.; Haverkamp, J. Sodium Cationized Oligosaccharides do not Appear to Undergo Internal
Residue Loss Rearrangement Processes on Tandem Mass Spectrometry. Rapid Commun. Mass Spectrom. 1998, 12, 1520-1532.

37. Gronberg A.; Eriksson E.; Sinangil F.; Ronnholm M.; Feizi T.; Minden P. Kiessling, R. J. Comparison Between Murine Natural Antibodies and Natural Killer Cells: Recognition of Separate Target Structures as Revealed by Differential in Vitro Expression and Dependence on Glycosylation. I. Natl. Cancer Inst. 1985, 74, 67-75.

38. Mercurio, A. M. Disruption of Oligosaccharide Processing in Murine Tumor Cells Inhibits Their Susceptibility to Lysis by Activated Mouse Macrophages. Proc. Natl. Acad. Sci. U.S.A. 1986, 83, 2609-2613.

39. Block, T.; Mehta, A.; Fimme, C. J.; Jordan, R. Molecular Viral Oncology of Hepatocellular Carcinoma. Oncogene 2003, 22, 5093-5107. 